\title{
Forest Management Teams, a Citizenship Paradigm Analysis through Influence and Importance Factors; Experience from Arabuko Sokoke Forest, Kenya
}

\author{
Mũsingo T. E. Mbuvi1 ${ }^{*}$, Josephine K. Musyoki², Leila A. Ndalilo³ \\ ${ }^{1}$ Principal Research Scientist, Kenya Forestry Research Institute Headquarters, Nairobi, Kenya \\ ${ }^{2}$ Senior Research Scientist, Kenya Forestry Research Institute, Dryland Eco Region Research Programme, \\ Kitui, Kenya \\ ${ }^{3}$ Research Scientist, Kenya Forestry Research Institute, Coast Eco Region Research Programme, Kenya Forestry Research \\ Institute, Malindi, Kenya \\ Email: *mtembuvi@gmail.com
}

How to cite this paper: Mbuvi, M. T. E., Musyoki, J. K., \& Ndalilo, L. A. (2020). Forest Management Teams, a Citizenship Paradigm Analysis through Influence and Importance Factors; Experience from Arabuko Sokoke Forest, Kenya. Open Journal of Forestry, 10, 81-109.

https://doi.org/10.4236/ojf.2020.101007

Received: August 29, 2019

Accepted: December 28, 2019

Published: December 31, 2019

Copyright $\odot 2020$ by author(s) and Scientific Research Publishing Inc. This work is licensed under the Creative Commons Attribution International License (CC BY 4.0).

http://creativecommons.org/licenses/by/4.0/

(c) (i) Open Access

\begin{abstract}
The multiple uses of forests continue to draw interest from diverse stakeholders. Forest Management Teams model has been used to accommodate the interests of stakeholders and facilitate better forest management and improve community livelihoods through managed citizenship. In Kenya, the model has been practiced the longest in Arabuko Sokoke forest. This paper reviews the 25-year-old Arabuko Sokoke Forest Management Team using the Influence and Importance tool. The assessment demonstrates that Influence and Importance factors affect forest management either positively or negatively, fair and just use of this tool could lead to a team (citizenship) that is perpetually adapting to new tasks and emerging scenarios where local communities and stakeholders are empowered by new rights conferred to them by the partnership. In Arabuko Sokoke forest, the use of Forest Management Team has achieved enviable success in forest management, community livelihoods, organizational development and rural development-which are essential elements for forest citizenship. This paper documents how appropriate application of Influence and Importance tool bounded by external and internal actors can enhance an inclusive and adaptive participatory process.
\end{abstract}

\section{Keywords}

Stakeholders, Influence, Importance, Citizenship and Teams 


\section{Introduction}

In many developing countries, there has been a paradigm shift on forest management where local people and other stakeholders are playing a more active role through devolution of forest management to community forest associations and allied Community based organizations (Banana et al., 1999; Coulibaly-Lingani et al., 2011). This has been referred to as "managed citizenship" where local communities and other stakeholders are empowered by rights acquired through a partnership that has been influenced by globalization (Tysiachniouk \& Laura, 2015). This has been necessitated by the failure of command and control management approach to address the needs of the local people and involve them in forest management. Evidence from other countries like Tanzania, Uganda, Nepal and India has shown that involving local people in forest management leads to improved forest condition and community livelihoods (Banana et al., 1999; Coulibaly-Lingani et al., 2011; Phiri et al., 2012; Matiku et al., 2013). Multi-stakeholder engagement has educated the community and other stakeholders of their rights, enhanced the livelihoods status, democracy and enabled the community to engage other stakeholders as noted by Tysiachniouk \& Laura (2015). This approach was designed to enhance citizenship approach through building institutional capacity, linking policies across sectors (integrated and conservation projects) and involving Civil Society Organization (CSOs) and Community Based Organizations (CBOs) in forest management decision making (Schmink, 2011). In the Kenyan context, a civil society is an organization registered as a company and has a right to sue, can be sued and can own property. It is mainly involved in advocacy and lobbying but also engages in development aimed at empowerment of local people.

In Kenya, forest sector reform has been premised on decentralization of forest resources supported by legislative reform (Wass, 1995; Government of KenyaGoK, 2010; Kenya Forest Service-KFS, 2015a; GoK, 2016a; GoK, 2016b) and institutional reform with emphasis on the importance of local people participation in forest management. This had led to the formation of structures parallel to state institutions for citizens (community) in forests as noted by Tysiachniouk \& Laura (2015). In Kenya, community, government, civil societies, NGOs and other stakeholders participate in forest management. These changes have become a crucial component of environmental policy as evidenced by several legislations (GoK, 2016a; Ministry of Environment, Water and Natural ResourcesMEWNR, 2015; KFS, 2015b). These are outcomes of global influence (Tysiachniouk \& Laura, 2015) which have created local legal opportunities that have led to formation of groups like Community Forest Associations (CFAs) (Kenya Forest Service-KFS, 2009), Forest Conservation Committees (GoK, 2016a) and Forest Management Teams (FMTs) (Forest Department, 2002; Arabuko Sokoke Forest Management Team-ASFMT, 2005; KFS \& Kenya Wildlife ServiceKWS, 2012). These legal and organizational restructuring is happening in gazetted forest reserves under government management where citizen participation is 
allowed through exclusive regulations. Legally CFAs are the CBOs through which citizens are allowed to participate in forest management (KFS, 2015a; KFS, 2015b; GoK, 2016a). In Kenya, CBOs are grass root membership organizations formed by members of communities and registered by department of Gender and Social services. Legally they cannot own property neither can they sue and be sued. They also engage in advocacy and lobbying.

The concept of Forest Management Teams (FMTs) in Kenya can be traced to early 1990 (MENR, 1994) when forest management through multi-agencies and non-state actors was introduced through the Kenya Indigenous Forest Conservation (KIFCON) project (Wass, 1995). This was a project that was implemented under the FMT model in several forests in the country with the pilot being done in Arabuko Sokoke (ASF) and Kakamega forests. Though the FMTs started as "invincible social groups" as noted by Schmink (2011), they struggled to be established and have established external networks to support their growth, mobilized partnerships and resources and are able to articulate their agenda as happened to the Acre case in Brazil (Schmink, 2011). The FMTs have remained resilient, undergone tremendous growth and transformation and have been formalized in forest management (GoK, 2016a).

In ASF, KFS and KWS formed a team to enhance forest management through Memorandums of Understandings (MoUs) which incorporated other government agencies through subsequent MoUs and Addendums to include Kenya Forestry Research Institute (KEFRI) and National Museums of Kenya (NMK) as indicated in the ASF strategic management plan (Arabuko Sokoke Forest Management Team, 2002). This was aimed at addressing a trend where different types of organizations and groups which, although concerned with the same resources, often act independently and have different and sometimes conflicting perceptions, values, objectives and even knowledge systems (Anderson et al., 2012: p. 2). The MoU and Forest Management Agreements/Memorandum of Agreements (MoA) defined the roles of each partner and how the Team was to manage its operations but they were not legally binding partnerships. The Teams also played "environmental activism" in order to mitigate political influence, economic interest for land, deforestation and wildlife poaching which associated the global south with the global north as noted by Benito (2015), a partnership that supported conservation and contributed to poverty reduction. The communities and other ASF stakeholders have formed transnational networks that have enabled them to exercise their citizenship right domestically and globally as noted by Tysiachniouk \& Laura (2015).

The FMT in ASF provided a framework that allowed the institutions to implement assignments without being confined to the mandates so as to allow the system to evolve. They allowed mechanisms and organizational structures that enabled citizens to participate in forest management and livelihood improvement and enhancing governance (Benito, 2015). This partnership enabled ASF to develop the first ASF 25-year strategic plan (Forest Department, 2002) that invigorated planning in the forest sector in Kenya. Further, the FMTs or "ma- 
naged citizenship" have witnessed local communities and partners empowered by national and global governance models and networks as noted by Tysiachniouk \& Laura (2015).

The FMT in ASF is an informal institution as noted by Jacobs (2017), does not have administrative charters but has socially shared rules in most cases unwritten that are communicated and applied (hardly enforced) outside of the formal systems. The law provides for teams/partnerships. The Forest Conservation and Management Act 2016 (GoK, 2016a) provided for formal agreements through the development of Participatory Forest Management Plans (PFMPs) which are formalized through Forest Management Agreement (FMA) (KFS, 2015b). Though the initial Team differed from the government partner formal institutions which Jacobs (2017) indicated have rules and procedures that are created, communicated and enforced through regulated channels that are recognized as official, they are evolving to formal institutions.

\section{The Problem and Justification}

In 1980s, there was national concern regarding forest degradation in Kenya (MENR, 1994; Wass, 1995; GoK, 2016b) and a perceived consensus that communities and other stakeholders have the potential to reverse the trend if they are involved in the management of forests (GoK, 2016b). Kenya Forest Service then Forest Department (FD) was lowly funded and its offices under-resourced with few forest guards supported by patrolmen who were not trained. Civil societies were well resourced and donors preferred to work with or through them. This necessitated the need to develop partnerships that would bring on board all relevant stakeholders. Furthermore, globally forest management through partnerships was picking up with enviable results in Nepal and India (Hobley, 1996). The use of FMT as a management approach was introduced in ASF between 1997-2003, through the Arabuko Sokoke Management and Conservation project premised on integrated conservation and development approach. The project was implemented through FMT model involving multi-stakeholders. Piloting on Participatory Forest Management (PFM) as an alternative forest management approach, was one key ASFMT activity aimed at mitigating the challenge of unprecedented rates of forest degradation (Matiku et al., 2013). This challenge was partly caused by the implementers not adjusting to the new management paradigm, acting traditionally and exclusively as state officers and failing to appreciate that the project was operating at both local and global sphere where it was setting new rules that define new spheres of "legitimate working models (Tysiachniouk \& Laura, 2015). The Team was also not able to adequately appreciate that global governance serves the interest of some actors and may not be in sync with local actors in ASF. Despite the necessity and the potential, the project had to provide answers to the management challenges facing ASF and entire forest sector in Kenya, but it faced challenges making the ASF-FMT operational.

Initially, the FMT was not able to go beyond the forming stage due to frequent 
staff transfer, a factor that was affecting its implementation making delivery on the targets impossible. The other major challenge facing the project and the FMT was that the partnering organizations were acting both individually and as coalitions' and were using the power conferred to them by legislations (mandate) and influence it enjoyed individually and through associations to have their interests override that of others. Improper use of these factors by the partners was negatively impacting the project and affecting the FMT efficiency. This paper demonstrates how through Influence (In) and Importance (Im) tool, the team was able to undertake a self-reassessment and move to the performing stage and deliver on its targets. It also illustrates how the tool would be used to create FMTs as "managed citizenship", and periodically assess their contribution in meeting forest management objectives. It will provide managers with a framework to continuously assess teams and individual members' contribution and periodically facilitate the Team adjust in order to adapt to changing forest management needs and team demands.

\section{Methodology}

\subsection{Study Site}

The Arabuko-Sokoke Forest Reserve (ASFR) is a coastal forest adjacent to the Indian Ocean next to Mida creek mangrove forests located in Kilifi County in the Coast region of Kenya (Figure 1). It is approximately $420 \mathrm{~km}^{2}$, was declared a crown forest in 1932 and gazetted in 1942. Before then it was managed by communities and sultanate management system. It is managed by the Kenya Forest Service (KFS) of the Ministry of Environment and Natural Resources (Forest Department, 2002). The forest has a hot and humid coastal climate and receives over $1000 \mathrm{~mm}$ of rainfall per year spread over two rain seasons: "short

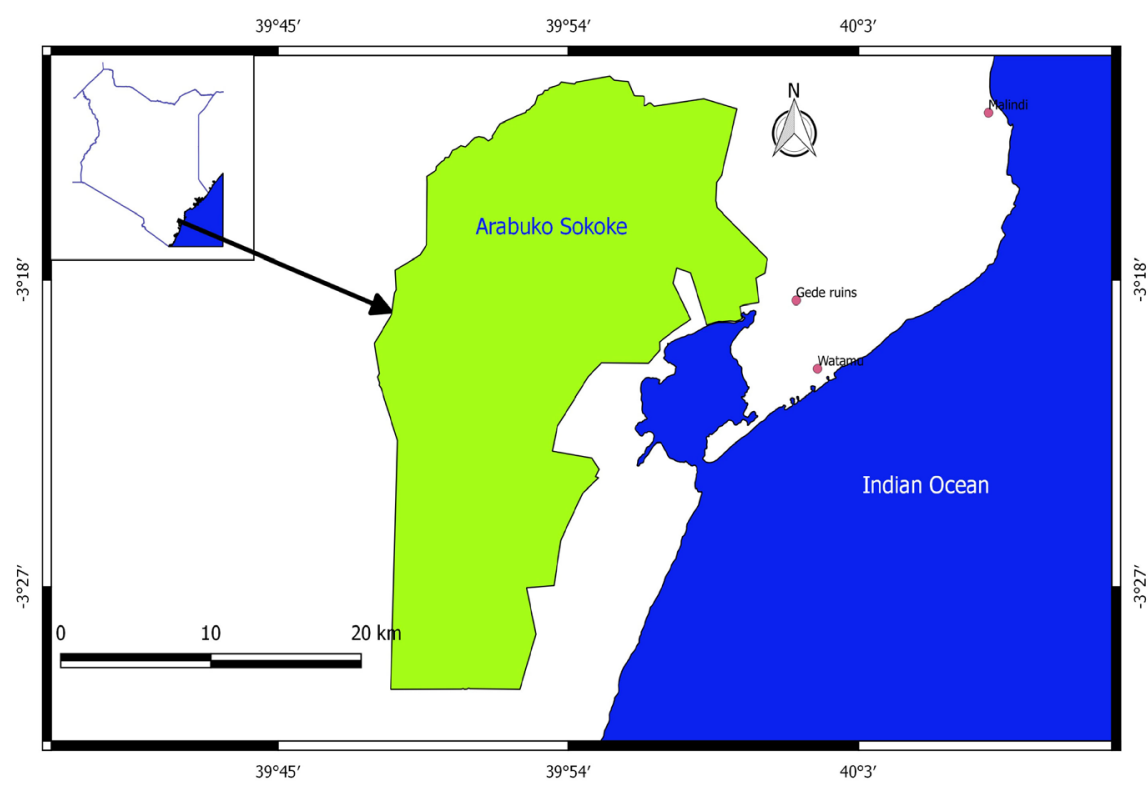

Figure 1. Arabuko Sokoke forest. 
rains" (October-November) and long rains (April-May). The area experiences annual average temperature of around $29^{\circ} \mathrm{C}$.

The forest was selected because it has both local, national and global citizen interest and they operate simultaneously as members of localized politicized global communities (Benito, 2015). The ASFR is globally important as a biodiversity hotspot (Myers et al., 2000) and is central to the subsistence of local communities. In 1998, there were 52 provincial administrative villages but these have almost doubled, standing at 94 by 2017. Landholdings were initially $12-18$ acres in the settlements but have reduced to $4-6$ acres on average with the sub-division of the parcels to provide a settlement for the younger generations (Mbuvi et al., 2007). The ASF citizens have created networks that are challenging the traditional, modern, automatic and exclusive associations of citizens within the national space, the partnerships (Teams) are bringing in additional spaces, relevant for exercising citizenship as noted by Benito (2015). For instance, in the 1990s' the stakeholders especially the community employed citizenship in the struggle against degazettement and exploitation of the forest and demanded inclusion in forest management and participation in decision making as noted by Benito (2015).

\subsection{Data Collection Methods}

The data was collected through a literature review, Key Informant interviews and Focus Group Discussion (FGD) between 2016 and 2018. Literature review from ASF project reports and reports from forests under a similar management system was undertaken. These included reports from forests which are being managed through partnerships to enhance community participation and better forest management. Key Informant (KI) interview was undertaken on 35 persons known to have interest in ASF management, participated in lobbying for conservation of the forest and had participated in forest management activities in ASF. The discussions were guided by an interview guide which focused on historical assessment of ASF management, what factors contributed to better or poor forest management and the institutional structural changes and how this was affected by power and influence and the effect it has had on forest management and stakeholder partnerships. Their long-term observation of forest management trends and activities in ASF gave them insights about the forest and the managers and they were able to make inferences on situations.

The "ideal" KI was selected based on the characteristics prescribed by Tremblay quoted in Marshall (1996) including; role in the community, knowledge, willingness, communicability and impartiality. The informants were selected from five groups; government, NGO, civil society, CBOs and Community with five individuals being interviewed from each group except the community where 15 participants (KIs) were selected. A snow-balling approach (Mugenda \& $\mathrm{Mu}$ genda, 1999) was used whereby interviewees were asked to propose further KIs they considered to have relevant experience, and these were added to the sample until no new names were mentioned. KI was appropriate in understanding the 
underlying motivations and attitudes of the target population in order to generate suggestions and recommendations as noted by (Kumar, 1989). Six FGD were undertaken with groups of 10 to 15 participants (Freitas et al., 1998; Folch-Lyon \& Trost, 1981; Boateng, 2012) selected with the help of KIs. The discussions were guided by a checklist and recorded in a notebook. The FGD was used to discuss trends on; forest management, project implementation approaches and outcomes, and working relations between managers and the community, as well as the various partners in ASFMT.

\section{Results and Discussion}

\subsection{The Paradigm: The Forest Management Team Perspective in ASFR}

In ASFR, as in other forests under similar regimes, there is a FMT; Arabuko Sokoke Forest Management Team (ASFMT). The team has grown with time from two institutions (KFS and KWS) in 1990 and by 2000 it was composed of four government departments: Kenya Forest Service (KFS); Kenya Forestry Research Institute (KEFRI); Kenya Wildlife Service (KWS) and National Museums of Kenya (NMK) through the Kipepeo (Butterfly) farming project and the community (Balozi et al., 2003; Ming'ate et al., 2014) (Figure 2). The team expanded to include additional or temporary membership of organizations (NGOs) with long term programs/projects in the forest to be co-opted members of the ASFMT over the durations of their programs. The latter organizations are not subjected to conditions applicable to state actors and brought in new rules, new resources, unfamiliar working procedures, contradictions and conflicts (Tysiachniouk \& Laura, 2015). These destabilized (referred to as denationalization by Tysiachniouk \& Laura (2015) the government institutions due to the association with
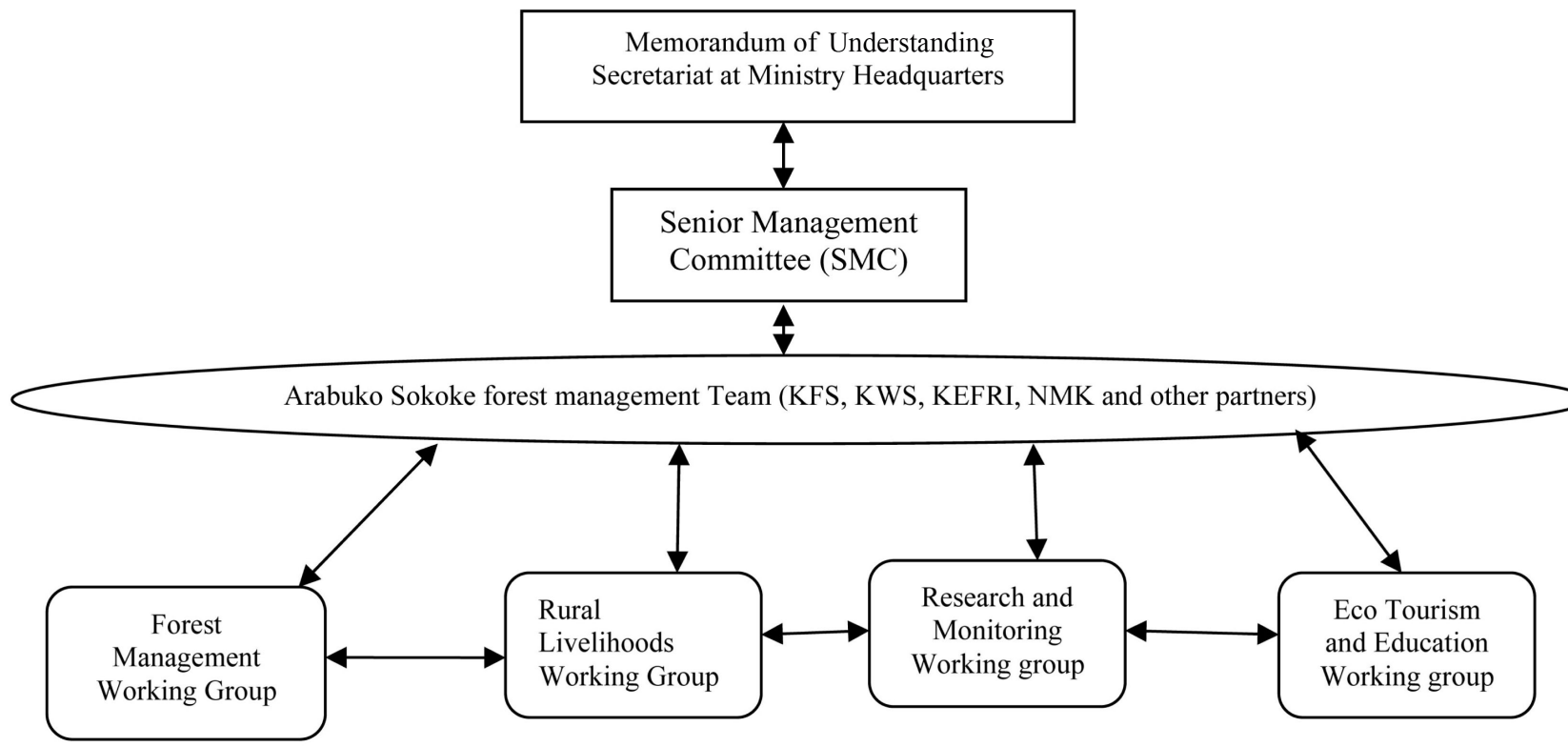

Figure 2. ASFMT organizational structure. 
globalizations. This was witnessed in the mandates and the key focus of the ASFMT stakeholders ranged from supporting forest conservation, education through bursaries, lobbying and advocacy, rural development, ecotourism and forest management and research. This was achieved through a project funded through international NGO (Birdlife International) and CSO (Nature Kenya). The NGOs and CSO brought to the Team environmental justice discourse (Benito, 2015) through community involvement in forest management and inclusion of their views in decision making referred to as indigenous citizenship (Benito, 2015).

The ASFMT organizational structure could be compared with the Caribbean Landscape Conservation Cooperative (CLCC) as explained by Jacobs (2017) in that it is a partnership effort strategically created to conserve the forest but with a landscape goal and more than forest strategy that strives to be efficient with well-defined targets supported by Team approaches on how the team outputs will be delivered as per the teams purpose. They have also been referred to as multi-stakeholder platforms (MSPs) to foster effective, cooperative and inclusive governance based on public participation, collective action and conflict mitigation (Brenner, 2019). This provides what has been referred to as multi-layered citizenship by Tysiachniouk \& Laura (2015) through the proliferation of organizations with authority at different levels of governance which has increased the number of multiple and overlapping citizenships with a possibility of institutionalization. The ASFMT organizational structure design enables adaptation of activity coordination and implementation within the changing paradigm. The Team is held together by unique cultural identity, rooted defense of the forest, to promote forest-based development based on sustainable use of resources as was the case in Acre Brazil as noted by Schmink (2011). The Team has activity implementation committees referred to as Working Groups (WG). The Senior Management Committee (SMC) is the overall management organ that forwards works plans for approval to the MoU secretariat and coordinates and undertakes monitoring and evaluation of the team and individual organization activities.

The WGs include; forest management WG which ensures that forest management is well-coordinated and brings on board diverse stakeholders. Rural development and livelihoods WG involved in undertaking Participatory Rural Appraisal, community capacity development and overseeing the implementation of livelihood activities in community lands adjacent to the forest. Tourism development WG ensures that the forest eco-tourism potential is developed while building the capacity of both government, civil society and community to invest in tourism both in the forest and in community land individually and through partnerships like for Arabuko Sokoke Forest Guides Association (ASFGA). Education and environmental awareness creation WG targets all stakeholders with more emphasis on schools, youth and forest adjacent community to facilitate the management change. Research and monitoring WG provides information to guide forest management and particularly support the new management system. 
Forest management teams as the case in ASFR are an emerging management framework that has evolved for a long time. This approach is a-joint-partners management-driven, landscape-oriented, focused on users, future-focused and premised on shared vision, and is rooted both on social, and ecological requirements as it engages on poverty reduction, food security and rural development which deviates from age-old science-based forest management (Jacobs, 2017). This management engages with industry, partners (local and international) and brings to the fore people concerns including wealth creation, fairness and equity and good governance requirements as was noted by Jacobs (2017), which are essential elements of forest citizenship. In ASF, as is the case in Kakamega, the forest engages with tourism industry through community forest guides, bird watching, bandas ${ }^{1}$ and snake farm, butterfly farming, silk moth farming, Ocimum kilimandischaricum oil processing, Mondia whyteii root food supplement powder processing for income generation among others. Stakeholder involvement in ASFR has increased over time as the FMT evolved (Table 1).

The ASFMT model presents an arrangement where both numbers of stakeholders and the stakes are high, the participatory process is strongly influenced by relationships thus the coalitions of interests and the balance of power among the participants as noted by Paletto et al. (2016) will be a critical process. Further, the ASFMT retained multiple identity and function in the Team; the individual organizations have their organizational mandates, roles and activities and have responsibility for those activities assigned to them by the Team which they implement separately or jointly (as part of the team). This calls for continuous stakeholder analysis and partnership guide through the ASFMT guidelines (ASFMT, 2005) which allow ASFMT to expand their stakeholders, increase or reduce (merge) number of working groups based on funding and the tasks ahead. This model borrows from pluralism as described by Anderson et al. (2012) which describes situations where distinct groups are actively autonomous and independent, but often interdependent, with legitimate claims and different positions on critical substantive issues as the case with the diverse partners in ASF. This scenario was noted by Tysiachniouk \& Laura (2015) where the guidelines are designed (in case of Kenya adapted from Nepal and India), adopted or adjusted to the local situation by the local site of implementation. The organizational roles and mandates of partners in the ASFR FMT are elucidated in Table 2.

\subsection{Community Structures}

During the 1997-2003 Arabuko Sokoke forest conservation project, the forest adjacent community was facilitated to form a community association; Dida Village Development and Forest Conservation Committee (VDFCC) (Figure 3) which later transformed to Dida Forest Adjacent Area Forest Association (DIFAAFA). This later transformed into Dida Community Forest Association,

${ }^{1}$ Accommodation facilities in forest areas mostly run by community groups mostly build with local materials like grass and mudwalled. 
Table 1. Evolution of forest management team in ASFR.

\begin{tabular}{|c|c|c|c|}
\hline Period & Responsible Organization & $\begin{array}{c}\text { Other } \\
\text { stakeholders }\end{array}$ & $\begin{array}{c}\text { Major } \\
\text { characteristics }\end{array}$ \\
\hline Before 1890 & Community & Traders & $\begin{array}{l}\text { The forest was managed } \\
\text { through local communities } \\
\text { and the sultanate. } \\
\text { High-value indigenous } \\
\text { tree species were exploited }\end{array}$ \\
\hline 1890 to 1990 & $\begin{array}{c}\text { Forest Department } \\
\text { (later Kenya Forest Service-KFS) }\end{array}$ & $\begin{array}{l}\text { Community } \\
\text { and Donors }\end{array}$ & $\begin{array}{l}\text { The community did not } \\
\text { have legal right over the } \\
\text { forest resources but the } \\
\text { law allowed them to access } \\
\text { defined products through } \\
\text { a unitary defined procedure } \\
\text { Donors focusing } \\
\text { on tree species trials }\end{array}$ \\
\hline 1992 & KFS; KWS; KEFRI and NMK & $\begin{array}{l}\text { Community } \\
\text { Donor }\end{array}$ & $\begin{array}{l}\text { Team very strong } \\
\text { Very strong Donor presence }\end{array}$ \\
\hline 1997 & $\begin{array}{c}\text { KFS; KWS; KEFRI; NMK; } \\
\text { Community and Friends of } \\
\text { Arabuko Sokoke Forest (FoASF) }\end{array}$ & $\begin{array}{c}\text { Donor } \\
\text { Civil society }\end{array}$ & $\begin{array}{l}\text { Team forming } \\
\text { Very strong Donor } \\
\text { presence and } \\
\text { active civil society } \\
\text { Government piloting } \\
\text { participatory forest } \\
\text { management system }\end{array}$ \\
\hline 2005 & $\begin{array}{l}\text { KFS; KWS; KEFRI; NMK and } \\
\text { Community (CFA, ASFADA) }\end{array}$ & $\begin{array}{c}\text { Donor } \\
\text { Civil society }\end{array}$ & $\begin{array}{l}\text { Team very strong } \\
\text { Team implementing }\end{array}$ \\
\hline 2010 & $\begin{array}{l}\text { KFS; KWS; KEFRI; NMK and } \\
\text { Community (CFA, ASFADA) }\end{array}$ & $\begin{array}{c}\text { Donor } \\
\text { Civil society }\end{array}$ & $\begin{array}{c}\text { Team very strong } \\
\text { Team implementing } \\
\text { Government facilitating } \\
\text { other partners } \\
\text { Partnership working } \\
\text { with minimal conflicts }\end{array}$ \\
\hline 2018 & $\begin{array}{c}\text { KFS; KWS; KEFRI; NMK; } \\
\text { Community (CFA, ASFADA) } \\
\text { and FoASF }\end{array}$ & $\begin{array}{c}\text { Donor } \\
\text { Civil society } \\
\text { Private investors } \\
\text { Mining companies } \\
\text { Nature lovers }\end{array}$ & $\begin{array}{l}\text { Team very weak } \\
\text { Team storming } \\
\text { The team faced conflicts } \\
\text { Government weakening } \\
\text { and civil society } \\
\text { getting strong } \\
\text { The team not able to } \\
\text { manage external } \\
\text { influence with potential } \\
\text { to have a negative effect } \\
\text { on forest management }\end{array}$ \\
\hline
\end{tabular}

the first Community Forest Association (CFA) to be formed in Kenya (Ongugo et al., 2008). This is the equivalent of Community Forest User Group (CFUG) of Nepal (Thakur, 2011). This was the pre-cursor to the national wide Community Forest Associations (KFS, 2009) that have been formed all over the country by forest adjacent communities as a means for their legal participation in forest management. 


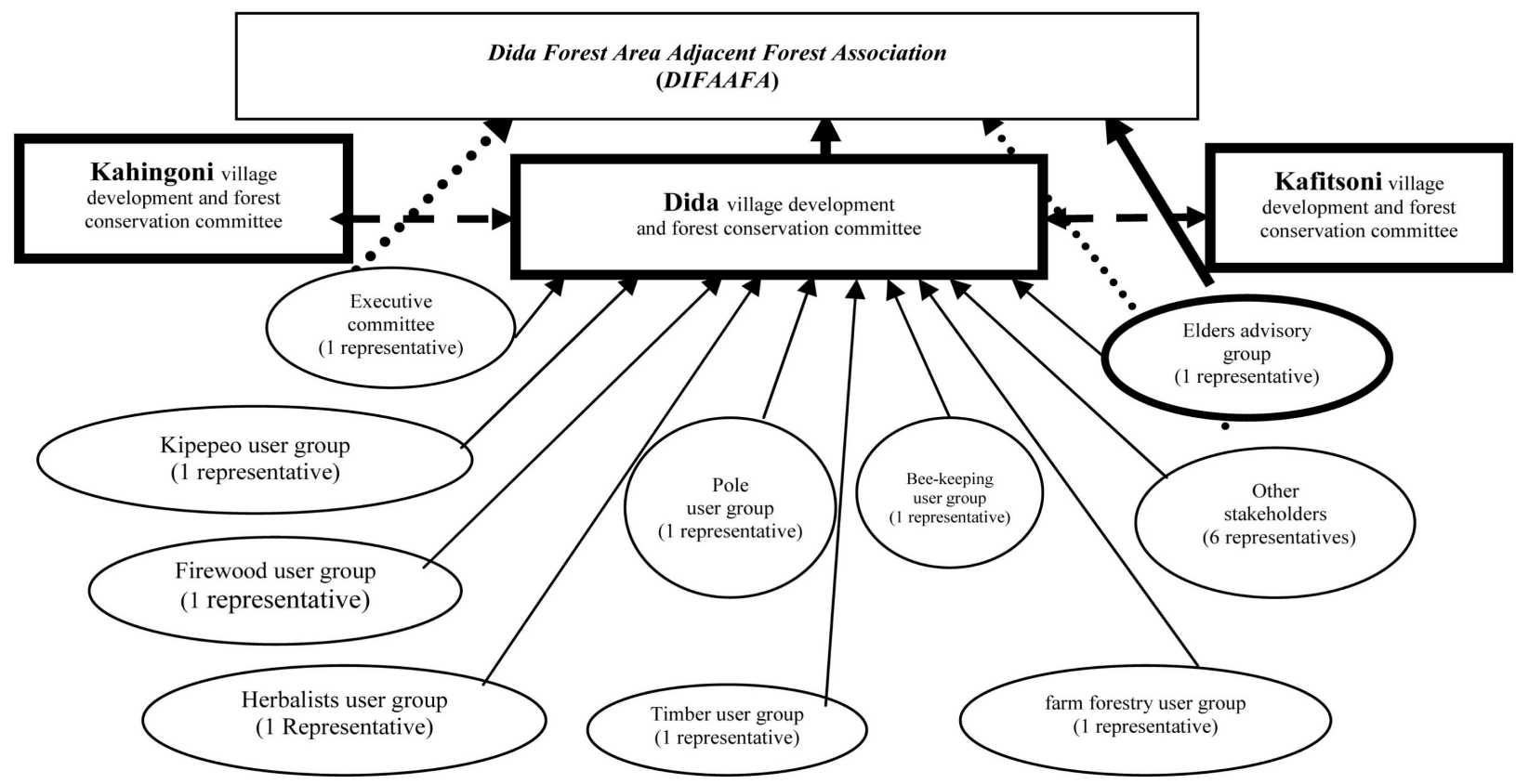

Figure 3. DIFAAFA organizational Structure.

Table 2. Mandate and roles of partners.

\begin{tabular}{|c|c|c|}
\hline Organization & Mandate/role & Additional roles assigned under FMTs \\
\hline Kenya Forest Service & Forest management & $\begin{array}{l}\text { - The responsible body for Forest management } \\
\text { decisions with legal implications. } \\
\text { - } \quad \text { Its sanction affect forest-based projects } \\
\text { - } \quad \text { Donors in some instances require KFS concurrence } \\
\text { - Endorsing Participatory Forest } \\
\quad \text { Management for national implementation. }\end{array}$ \\
\hline $\begin{array}{l}\text { Kenya Forestry } \\
\text { Research Institute }\end{array}$ & $\begin{array}{l}\text { Research in forestry } \\
\text { and allied natural resources }\end{array}$ & _ Piloting PFM and new IGAs \\
\hline Kenya Wildlife Service & Wildlife management & $\begin{array}{l}\text { - Spearheading programs on education and awareness } \\
\text { - Enhance eco-tourism development in the forest } \\
\text { - Human-wildlife conflict management }\end{array}$ \\
\hline National Museums of Kenya & $\begin{array}{l}\text { Conservation and management of Kenya's } \\
\text { heritage and collection of cultural, ecological } \\
\text { and fossils exhibits, sites and monuments } \\
\text { which are unique in Sub-Saharan Africa }\end{array}$ & $\begin{array}{l}\text { - Lead in introducing new income-generating } \\
\text { activities and other rural development projects } \\
\text { in the community such as butterfly farming }\end{array}$ \\
\hline $\begin{array}{c}\text { Arabuko Sokoke Forest } \\
\text { Adjacent Dwellers Association }\end{array}$ & $\begin{array}{l}\text { Livelihood and lobbying } \\
\text { and forest management }\end{array}$ & $\begin{array}{l}\text { - Mobilize communities to support forest management } \\
\text { - } \quad \text { Lobbying and advocacy }\end{array}$ \\
\hline $\begin{array}{l}\text { Dida Forest Adjacent } \\
\text { Area Forest Association }\end{array}$ & $\begin{array}{l}\text { Livelihood and lobbying } \\
\text { and forest management }\end{array}$ & $\begin{array}{l}\text { - Enter into an agreement with KFS } \\
\text { to pilot PFM in Kenya }\end{array}$ \\
\hline Civil society & $\begin{array}{l}\text { Livelihood development, lobbying } \\
\text { and forest management and fund raising }\end{array}$ & - Education, livelihood and advocacy \\
\hline Donor & $\begin{array}{l}\text { Fund raising, enhancing forest } \\
\text { management and facilitating } \\
\text { forest management paradigm shift }\end{array}$ & $\begin{array}{l}\text { - Provided funds through NGO who also provided } \\
\text { technical support that was needed to improve forest } \\
\text { management and specifically introducing PFM }\end{array}$ \\
\hline $\begin{array}{l}\text { Memorandum of } \\
\text { Understanding Secretariat } \\
\text { at the Ministry of } \\
\text { Environment and Natural } \\
\text { Resources Headquarters }\end{array}$ & $\begin{array}{l}\text { Ensuring MoU management } \\
\text { paradigm works and PFM pilot }\end{array}$ & $\begin{array}{l}\text { Multi-agency committee for overseeing the } \\
\text { management of projects in forests managed } \\
\text { under MoUs }\end{array}$ \\
\hline
\end{tabular}


As this was happening conservation-oriented elders and few local elites adjacent to ASF formed Arabuko Sokoke Forest Adjacent Dwellers Association (ASFADA) to lobby against degazettement of the forest. This was formed as a social movement stimulated by activism (Schmink et al., 2014) and vision for conserving the forest. Their vision has been carried forward through alliances with local professionals and partners as happened with the Acre Rubber Tappers in Brazil (Schmink et al., 2014). The community organization has legally formed CFAs in each station in ASF; Gede, Jilore and Sokoke forest stations and retained the original umbrella community structure, ASFADA.

A forest institutional infrastructure was created in ASF and has been introduced and adjusted to local forest conditions to benefit from existing opportunities and minimize barriers (Tysiachniouk \& Laura, 2015) in all forests in the country where PFM is being implemented. ASFADA, a community organization has so far sourced funds for three projects in ASF: construction of an elephant deterrent fence around the forest; construction of a community tourist hotel with conference facilities attracting both local and international clientele and nature-based enterprises like beekeeping and butterfly farming. The CFA structure of user groups has been endowed with rights and responsibilities in what has conferred to them citizenship (Tysiachniouk \& Laura, 2015). This ensures the groups practice social justice, citizenship rights, ethics, transparency and participation as noted by Schmink (2011). This has ensured that the poor are recognized and perceived as bearers of rights.

\subsection{Trend in Performance of Arabuko Sokoke Forest Management Team between 2000 and 2017}

The ASF forest management team has retained a same number of government partners but other organizations' membership has been changing with the highest change being witnessed with the community and the civil society organizations. Variation has been experienced in their function, diversity of projects and lead institution (Table 3). The forest has had donor support since 1990 with the number of civil society organizations varying though one (Nature Kenya) has remained dominant all through. The civil society enjoys an extensive network of partners nationally and globally, and can easily reform and re-engineer themselves to fit the donor needs and the prevailing socio-ecological scenarios. The community organizations enjoy the same latitude but have a limited network as compared to the civil society. These two can also easily terminate their engagement in the team and re-join at will. This is unlike the government organizations whose working systems are controlled by their mandates and require justification and lengthy approval process for any action. The evolution of Arabuko Sokoke Forest Project implementation partnerships is outlined in Table 3.

\subsection{The Framework: Influence and Importance (In \& Im) Analysis}

Influence and importance analysis assesses the level of interest of each stakeholder and generates insights on the ability of each stakeholder to sway decisions 
Table 3. Evolution of Arabuko Sokoke forest project implementation partnerships (1990-2016).

\begin{tabular}{|c|c|c|}
\hline Project Title and period & Major activities & $\begin{array}{l}\text { Project manager and } \\
\text { lead organization/s }\end{array}$ \\
\hline $\begin{array}{c}\text { Kenya Indigenous Forest } \\
\text { Conservation Project (KIFCON) } \\
1990 \text { to } 1993\end{array}$ & $\begin{array}{l}\text { - It demonstrated that there are formal and informal } \\
\text { forest benefits to communities. } \\
\text { - It demonstrated informal (illegal) benefits from ASF } \\
\text { were higher than legal benefits. } \\
\text { - Started initial attempts for community participation in forest } \\
\text { management. } \\
\text { - Facilitated the initiation of KWS participation in joint } \\
\text { management of ASF through a Memorandum of } \\
\text { Understanding (MOU). } \\
\text { The biggest challenge was legalizing, diversifying } \\
\text { and spreading benefits. }\end{array}$ & $\begin{array}{l}\text { ODA } \\
\text { KFS }\end{array}$ \\
\hline $\begin{array}{c}\text { Kipepeo (Butterfly) farming Project }{ }^{3} \\
\text { Ongoing since } 1993\end{array}$ & $\begin{array}{l}\text { - A conservation innovation that demonstrated } \\
\text { that communities could get higher returns from } \\
\text { non-timber forest products such as butterflies. } \\
\text { - Demonstrated that the attitude of the community towards } \\
\text { forest conservation is directly related to the benefits } \\
\text { they draw from it. } \\
\text { - Started ("opened eyes") first forest-based direct } \\
\text { non-consumptive benefits. } \\
\text { - By } 2000 \text { it started facilitating the sale of honey produced } \\
\text { by ASF Forest adjacent Communities (FAC) with an } \\
\text { equipped marketing processing center. } \\
\text { - The project has not received funding since } 2006 \text { but has } \\
\text { continued to grow sustainably. }\end{array}$ & $\begin{array}{c}\text { Nature Kenya (NK) } \\
\text { and NMK }\end{array}$ \\
\hline $\begin{array}{l}\text { Promotion of Sustainable } \\
\text { Forest Management }(\text { PSFM })^{4} \\
\text { 1993-1998 }\end{array}$ & $\begin{array}{l}\text { - Emphasized on sustainable management of natural forests. } \\
\text { - } \text { Initiated on-farm forestry. } \\
\text { conducted Participatory Rural Appraisal (PRA) to initiate } \\
\text { community involvement in PFM. }\end{array}$ & $\begin{array}{c}\text { GIZ } \\
\text { KEFRI }\end{array}$ \\
\hline $\begin{array}{l}\text { Arabuko-Sokoke Forest Management } \\
\text { and Conservation Project (ASFMCP) } \\
\text { 1997-2001 }\end{array}$ & $\begin{array}{l}\text { - Build the capacity of Government officers and community } \\
\text { to support the forest management paradigm shift. } \\
\text { - Initiated PFM piloting and integrated rural development. } \\
\text { - Expanded existing forestry-related Income Generating } \\
\text { Activities (IGAs) and initiated new IGAs like beekeeping } \\
\text { and Aloe growing. } \\
\text { - Enhanced ASFMT and community partnerships and structures. } \\
\text { - The government increased funding towards multiple } \\
\text { stakeholder management. }\end{array}$ & $\begin{array}{c}\text { Birdlife International } \\
\text { MoU secretariat at } \\
\text { Ministry headquarters } \\
\text { composed of KFS, KWS, } \\
\text { KEFRI, NMK and } \\
\text { USAID representative }\end{array}$ \\
\hline $\begin{array}{l}\text { Arabuko-Sokoke Forest Community } \\
\text { Conservation Initiatives } \\
\text { 2003-2005 }\end{array}$ & $\begin{array}{l}\text { - The project developed and implemented equally by } \\
\text { Government and Community. } \\
\text { Initiated human-wildlife conflict deterrent through the } \\
\text { construction of the electric fence and did the initial } \\
20 \mathrm{~km} \text { solar fence. } \\
\text { - Supported learning cross-site visits. } \\
\text { - Consolidating existing IGAs like Eco-Tourism, Butterfly } \\
\text { farming and Bee keeping. } \\
\text { - Initiating new IGAs like Mushroom farming. }\end{array}$ & ASFADA and ASFMT \\
\hline
\end{tabular}

${ }^{2}$ Funded by the Government of Kenya and UK through ODA the current DFID.

${ }^{3}$ Funded by the UNDP-GEF small grants, Chicago Zoological Society, IUCN Netherlands Committee, Japanese Embassy in Kenya, EU and USAID.

${ }^{4}$ Funded by the Government of Kenya and Germany through GTZ.

${ }^{5}$ Funded by the Government of Kenya and European Commission.

${ }^{6}$ Funded by the Government of Kenya and European Commission and the Forest Adjacent Community. 


\section{Continued}

Enhanced sustainability of Arabuko-Sokoke forest through Improved Natural Resources Management by and for Stakeholders 2003-2006
- Consolidating existing IGAs like Eco-Tourism, Butterfly farming and Bee keeping.

- Facilitating the completion of the PFM piloting, scaling up and starting a monitoring system.

- Building CBOs capacity in organization and advocacy.

- Initiated Aloe vera farming as a new IGA.

- $\quad$ Expanded PFM to cover two more sites in ASF.

- Awareness on PFM.

Developing Incentives for Community Participation in Forest Conservation Through the Use of Commercial Insects in Kenya ${ }^{8}$ 2004-2008

People and Sustainable Development: Investing in Education, and Social and Economic Empowerment to conserve globally threatened biodiversity in Arabuko-Sokoke Forest, Kenya ${ }^{9}$ 2004-2008

Arabuko Sokoke Landscape Project ${ }^{10}$ 2012-2015

Strengthening Community Capacity to adapt to Climate Change ${ }^{11}$ 2014-2015

Capacity building of Forest Adjacent Communities, Kenya ${ }^{12}$ 2015-2017
- Supported beekeeping and sericulture as IGAs.

- Expanded PFM to cover two more sites in ASF.

- Capacity building of communities.

- Improving household livelihood so that children live a better life through better farming methods and the use of NTFPs.

- Provision of water.

- Beekeeping.

- Initiated Farmer Field Schools (FFS).

- Improving household livelihood.

- Awareness on PFM.

- Capacity building of local communities.

- Elephant fence construction.

- Planting of drought-resilient crops.

- Establishment of tree nurseries.

- Poultry keeping.

- Capacity building of FFS.

- Capacity building of local communities.

- Enhancing the effectiveness of CFA.
Nature Kenya

MoU secretariat at Ministry headquarters composed of KFS, KWS,

KEFRI, NMK and USAID representative

International center for Insect Physiology and Ecology (ICIPE)

KFS, NMK

NK and NABU

ASFADA and ASFMT

ASFADA and ASFMT

Nature Kenya

*Adopted from Mbuvi \& Ayiemba, 2005; Ndalilo et al. (2017).

towards their preferred direction. The analysis using this tool was informed by power-play dynamics in conservation where in theory power is the capacity for influence based on the control of resources valued or desired by others. In the context of this paper, this tool was used to assess the priority given to satisfying the needs and interests of each stakeholder (importance) and the power a stakeholder has to facilitate or impede the achievement of conservation and development objective (influence). In the ASF scenario, this power faced challenges as the process outcomes could not be institutionalized without mandate which in this paper has been referred to as importance. In order for the project to attain the planned change, it had to use the power within the spaces of influence and importance recognizing that organization may influence the way of doing things but the process would only be nationalized after getting the support of an or-

\footnotetext{
${ }^{7}$ Funded by the Government of Kenya and the Government of United States of America.

${ }^{8}$ Funded by GEF and Government of Kenya.

${ }^{9}$ Funded by Germany Civil society (Kindernothilfe and Naturschdeutchland).

${ }^{10}$ Funded by EU through Community Development Trust Fund (CDTF).

${ }^{11}$ Funded by EU through Community Development Trust Fund (CDTF).

${ }^{12}$ Funded by Danish Ornithological Fund (Birdlife Denmark).
} 
ganization with the mandate (important). In order for the new approach to be piloted, the headquarters of the mandated organization in the case of ASF, KFS had to agree to decentralize (empower) to local-level actors in this case ASFMT.

This tool was used at a time when the country was expecting answers from a piloting on PFM as management approach through FMT. The Arabuko Sokoke Management and Conservation project was in its fourth year of implementation of a national PFM pilot as an alternative forest management approach in Kenya, yet it was not progressing well. The Team spirit in ASF was very low and the Team was beset by conflicts. The country was eagerly waiting for a solution to degrading forest and reducing forest area, declining Forest Department capacity, national loss of faith in KFS and low global support to the Kenyan forest sector (GoK, 2016b). The analysis was done through a participatory group discussion where participants (implementers, from ASFMT institutions) were invited to give their perspectives during training on how the two factors affect team performance. The application of In \& Im factors as management tools are discussed below.

\subsubsection{Influence as a Management Factor}

In the context of this paper, influence has been perceived as the ability to sway opinion and action like management decisions through others to meet the conservation and economic interests of their influencer or influencing agent and their caucus. Influence is the power to have an important effect on someone or something. In this paper, influence has also been used to refer to the organization's ability to ensure decisions are taken as per their interest. It may also imply the organization has the ability to force its way through even though it does not have the mandate. Influence has also been used to imply the capacity to have an effect on the character, development, or behavior of the other organizations and or staff to act as per the plans, intentions and interest of the influencer. Influence is the ability (of Influencer) to make a stakeholder (influence) pursue his interest or activity. This is based on the control of resources valued or desired by others (Turner, 2005).

The influencer may use expert knowledge, resources and networks to push for the planned outcomes by ensuring that the to-be-influenced believes that if the change or action is not done there will be repercussions which could be negative or positive. In forests which are bordered by different ethnic communities, the rich migrant may take up key CFA positions and the majority weak would not complain for fear of victimization. The influencing factors in this scenario include; ethnicity, wellbeing differences, knowledge, social status, relationships and elitism. The negative influence could be a transfer of an officer as a disciplinary action while a positive one could be a promotion, more support in terms of idea and recognition and fair appreciation of effort. This may include; 1) prominently supporting the activities by that individual and or organization to send a message that you need to join the winning team to be recognized and supported and 2) as in ASF project case, having PFM being accepted by the government as 
a national alternative forest management approach. These are efforts to influence actions, changes in line with what Turner (2005) referred to as the influencing agent.

A stakeholder has an influence on another when they are able to alter the other stakeholder's behavior through the application of pressure (Paletto et al., 2016). In Teams, access to resources is used to influence actions/decisions as noted by Paletto et al. (2016). Control of resources (finances) gives people power which enables stakeholders to gain and control organizations and Teams to support their activities or approaches. The influencer may apply persuasion as this is not about forcing one way but one of negotiating, convincing and validating the reality jointly within the group as noted by Turner (2005). The influence could be on a body that has coercive power (this could be for the individual organization, SMC or MoU secretariat) and indirectly produces the desired income. Influences reflect power based on resources. Turner (2005), defined power as the capacity to influence other people, that is conferred by the control of resources that are desired, valued or needed by others and which make them dependent upon the influencing agent for the satisfaction of their needs or reaching their goals and that different types of resources confer different types of power leading to different kinds of influence. The other influence tactics include manipulation, supplication, bullying, autocracy, disengagement and bargaining as noted by Simpson et al. (2015).

Persuasion is assumed to flow from information dependence on others to satisfy some purely individual need when the very need for and definition arises from the group and social relationships (Turner, 2005). In ASF, as in other forests in Kenya, influence was achieved through cross-site learning visits, expert influence through consultancies and attitude change through short and long-term training for change agents (influencers) which strengthened forest citizenship to have the forest management through FMT.

\subsubsection{Importance as a Management Factor}

Importance has been taken to be having the legal authority to ensure management is undertaken and all that has to be done has to have the sanction of this legal authority. In this paper it has been used to refer to the organization that has the mandate ${ }^{13}$ and legally its presence, concurrence, approval, acceptance, ratification, endorsement, sanction, authorization, in the participation is mandatory for a decision to be institutionalized or have wider acceptable application and impact. In this paper, the organization (that enjoys importance) has the authority to order, direct, instruct, command, require and change other stakeholders to act in a certain way. It has an assigned area of operation defined legally. This is the organization that may require to be influenced as well as being the influencer and also called the responsible body. Other organizations may assume this status through association and in situations where the mandated organization is not able to exercise their authority. Even in these situations, the team has to rely on

${ }^{13}$ Mandate is defined as an authorization to act given to a representative (https://www.merriam-webster.com/dictionary/mandate). 
the mandated institution as noted by Brenner (2019) since the influencer may not have a decisive stake in the governmental decision-making process. In the case of ASFR, the mandated (important) institution is KFS.

\subsubsection{Importance and Influence Practice}

Influence \& Importance should be looked at from a broad perspective encompassing the $\mathrm{CBO}$, the forest resource, their socio-economic status and their networks. This complexity requires a careful discerning and understanding to navigate through the realization that they are like two faces of the same coin as exemplified by their attributes. For example, do CBOs or Non-government actors have role or mandate in forest management or were their involvement envisaged? The Forest law in 1997 did not provide for such but as from 2007 when the Forest Act 2005 became operational and was subsequently revised in 2016 to align it to the constitution of Kenya 2010, provisions were made to provide the CBOs and NGOs with mandate or delegated roles and responsibilities, further calling for the need to understand the flux created by their legalized participation and involvement in forest management. This has been a leading theme in theory of practice of active citizenship which encompasses promoting and enabling local actors to participate in decision making and management of their forest resources as noted by Clarke \& Missingham (2009). The key attributes of Influence and Importance are elucidated in Table 4.

This was expounded by plotting of In \& Im in a graph through agreed consensus of participant perceptions (Figure 4). The graph was divided into four sections and organization plotted based on their perceived and or real effect of their In \& Im on the Team. Influence or Importance was classified as very low, low, high or very high. This is discussed in the framework elaborated in Figure 4.

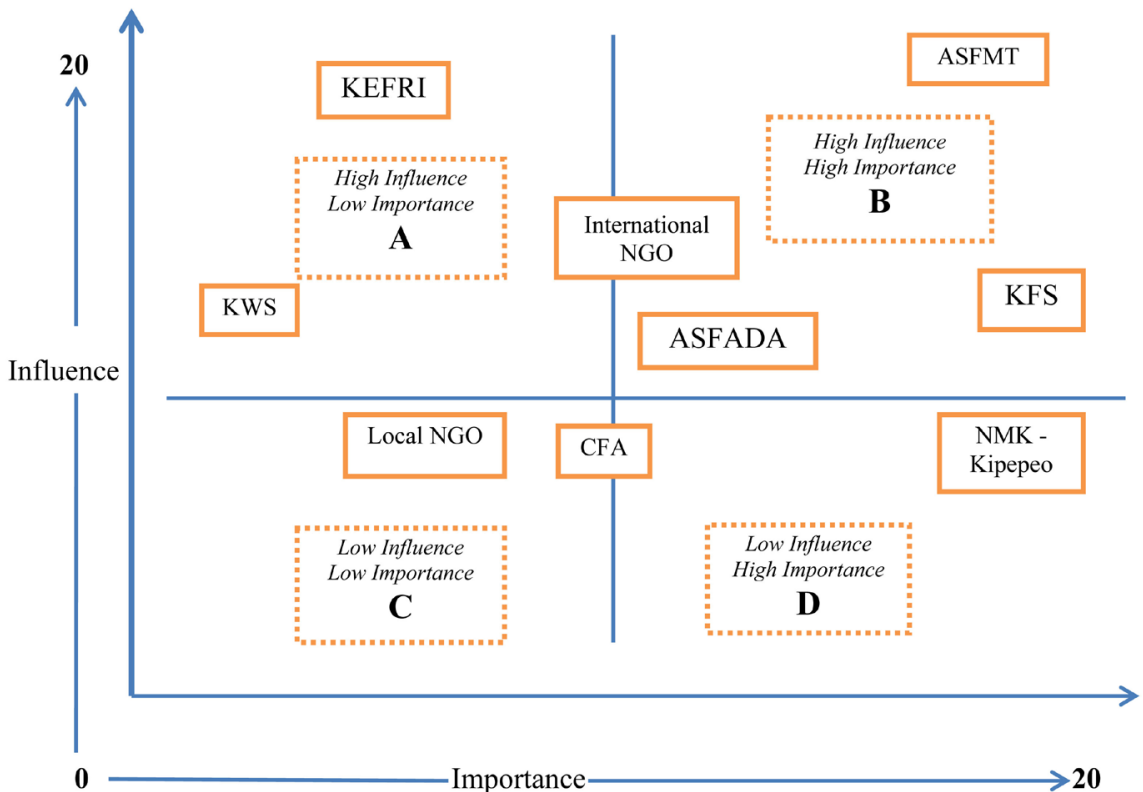

Figure 4. Analysis of the impact of Importance and Influence on forest management. 
Table 4. Attributes of influence and importance.

\begin{tabular}{lll}
\hline \multicolumn{1}{c}{ Influence } & \multicolumn{1}{c}{ Importance } \\
\hline - Ability to sway the position of others & - & Mandate (policy and legislation) \\
- The perception that the organization & - Skills and resource to execute the mandate \\
has capacity & Relations with other stakeholders \\
- The past record of the implementation & - & Ability to have decisions implemented \\
- Coalition forming & Coalitions (the interest to be \\
- Image created: we have the power to decide; & associated with success) \\
we know whom to talk to in order get a & - Recognition \\
solution or have you transferred & - Presence \\
if this is not done or repeated & - Image
\end{tabular}

The discussion draws from a comparative analysis done between the period when the Team was facing the critical challenge of not being able to hold together and when it was at peak performance. In 2000, the team was at the weakest and the major challenges faced by ASFR that were attributed to this scenario were: demand for de-gazettement of the forest to convert it to agricultural land; high incidences of wild animal (Lutz \& Newiadomsky, 2007) and tree poaching (Mbuvi et al., 2007) supported by booming tourism industry which offered a ready market for poached forest tree products; under-resourced forest protection unit served by one car for the entire county serving both management of indigenous forests, Mangroves, forest extension and forest administration coordination; weak forest management partnership with no community participation; poor forest adjacent community not involved in forest management; perceived corrupt forest managers fuelling forest products poaching and low political good will to conservation (GoK, 2016a).

The above situation could be attributed to the scenario noted by Anderson et al. (2012) that the different groups are all demanding a legitimate role in decision-making processes concerning natural resource management. These differences often seem to defy traditional attempts at consensus building and agreement. This situation was a major concern since the project had gone beyond the mid-term and high staff turnover affected the continuity of project activities. Though several approaches were tried, this paper reviews how Influence and Importance (In \& Im) factors affect forest management. This tool is participatory and self-interrogating and enabled individual officers and managers to assess how their conduct was enhancing the Team spirit and contributing either positively or negatively to ASFR conservation and project objectives.

An individual organization with influence and Importance Rank Level (RL) at 20 (Box B) risk uncontrolled influence on the team to implement what it wants. This dominant actor or stakeholder would be managed by a strong domineering supervisory organization to moderate the influence which could be exercised by the Ministry MoU secretariat or the ASFMT SMC. When an organization has Importance of level 2 and influence the rank level of 20 (Box A), it could result in conflicts and frustrations. The organization may push for implementation of good ideas which eventually do not go beyond the project. It will require having 
good skills in communication and may be good for a research organization whose results should influence change but are not legal instructions.

An organization in box D with importance rank level of 20 and influence rank level of 20 may push through the Team its activities or ideas without consensus or lead to the Team breaking up. The organization may use dominance power to ensure all other organization ideas stop, are slowed or are never approved. Organization in Box $\mathrm{C}$ with the importance of the rank level of 4 and influence rank level of 4 may result in its impact not being felt unless it outshines in implementing an activity that is of significant value to the Team, or the project and is picked up by the Team supervisor or very influential partners. Ming'ate et al. (2014) found that the communities felt that the government had not given them enough powers to manage and utilize resources (Box C). However, the PFM participating communities felt that they have right (Box B) of access to products through guidelines and agreements (Ming'ate et al., 2014).

The effect of an organization with Influence Rank level of 10 and the same for importance is likely to have its push for change in the project activities and outcomes never actualized and fail to achieve the anticipated change. From the above analysis, it is not advisable to have a single organization in a team being at either extreme where one is able to exert very low In \& Im or able to exert very high In \& Im as such a Team will not be able to function as expected.

In the diagram, it would expected that SMC should enjoy both Very High Influence and Very High Importance (VHIn \& VHIm) at RL of 20 or just about for the Team to work efficiently and also ensure that there is harmony and no single organization or a coalition of partners gets an opportunity to muzzle another or implement what is outside its mandate or what the Team has assigned. This would also ensure that the stakeholder bestowed the responsibility of facilitating project implementation works within the limits of equity and fairness. Any stakeholders assuming (acting against) this position would result in the Team being unstable, breeding mistrust and conflicts making the Team unable to meet its objectives. The role of the individual department (partner/s) would be moderated by the MoU secretariat.

The analysis of the ASFMT was done in 2003 and the situation has remained more or less the same with minimal variations. The situation has been cyclic, witnessed by periods of adequate funding and times of low funding. The former periods have been when there were funding and active donor, NGO, civil society and community participation. During such a phase, the FMT is normally very active and well organized while at times of low funding, there is low activity and poor team work, departments tending to work more individually with less and uncoordinated sharing of information. The Team is full of individual efforts even where one requires the support of the other team members leading to inefficient delivery on mandates. This happens because the team members, the organization and coalition of like-minded team member and organizations failing to bring up the influence, the ability or power of the team member. 
Analysis of the Team in 2003 when the Team was at its peak of performance, showed a Team that had stabilized with SMC exercising VHIn and VHIm in the Team over all the other stakeholders far from the situation in 1999 where it was perceived that KWS was the most influential (Box B) followed by KEFRI and NMK respectively with the ASF conservation project enjoying more superior status. The MoU secretariat played its role of monitoring and evaluation. The community through ASFADA was found to have the least influence in decision making regarding ASF management. ASFADA required active citizenship, develop its self-confidence and relatively enhance its power and develop the capacity to negotiate and influence decisions as noted by Clarke \& Missingham (2009). This would enable the community through ASFADA to enjoy legally and morally enforceable rights in relation to forest management. The NGOs and civil society were exercising very high influence and would coerce the government to take some decisions to enhance forest management. This provided an opportunity for the civil society to act as an influencing agent. This was though very unstable as it was highly dependent on the resources they had at the time. KFS despite its importance, exercised the least influence which drastically impacted in lowering the effect of its importance impact in the team.

SMC dominance (RL 20 for both In \& Im) was evident as there was a shift in the way stakeholders undertook their work not as "business as usual". Within the Team, one needs to know that one stakeholder who is more powerful may sway the decision of the Team representing the interest of one stakeholder but appears to be Teams influence (Simpson et al., 2015). Further, as noted by (Simpson et al., 2015) that individuals who have greater power in a relationship have the ability to exert greater influence on their partners when they want or need to, which allows them to achieve their desired goals more often. This was common in the Team in case of the civil society and the NGOs. It is worthy to be aware that the individual may act as a coalition of like-minded organizations.

This scenario contributed to most of the project activities in ASF including PFM, butterfly farming, Aloe vera growing and guinea fowl keeping being continued post-project lifespans unlike in most cases when projects are abandoned as noted by (Wattoo et al., 2010), since decision-makers considered the concerns and interests of other stakeholders and ensured adequate participation of related stakeholders. The need to influence others in ASF pushed for high levels of consultations, involvement and participation. This was an improvement from the earlier scenario whose contributing factors were: inadequate awareness about projects; low involvement of stakeholders in project management; failure to appraise the challenge of how much influence a stakeholder holds to sway decisions, and inadequate determination of the level of interaction with key players (stakeholders). The team also did not adequately know how important the stakeholder, external influence and the networks were.

From the ASF experience, the stakeholders who have influence tactics were able to affect the required change. The key influence tactics applied in ASF include; coercion, autocracy, reasoning and manipulation (Simpson et al., 2015). 
The conservationist's attitudes as was noted by Ansong \& Roskaft (2011) towards ASF management was influenced by their perception of forest values, concerns of increased forest degradation and livelihood concerns for forest adjacent communities.

In ASF, there was a concerted membership drive and at some point communities were paying to join the user groups (Mbuvi \& Musyoki, 2013) whose driving factor could have been as was noted by Ansong \& Roskaft (2011) in Ghana that belonging to a conservation group significantly influenced stakeholders' attitude with group members reporting positive attitude more than non-members. The positive attitude by the members and high interest in ASF as was noted in Ghana (Ansong \& Roskaft, 2011) was because elected members to various committees represented them. The members of the various committees were contributing to management decisions or regulations development and developed personal responsibility and feelings of having control over management initiatives, hence their positive attitude (Ansong \& Roskaft, 2011). The ASFMT members and the community gave them the chance to be motivated as ASFR was at one time the only forest being visited and consulted nationally to learn PFM and acted as the national influencer on PFM.

KEFRI had high influence than KFS in 1999 because it was leading the PFM pilot research to inform policy (Figure 5). The Team emphasized its autonomy and was able to universalize (Schmink, 2011) its approach by forging a partnership with other groups and dealing effectively with government. This situation changed in 2003 when the process started being implemented as an alternative management approach where KFS had to start playing (getting more influential) a more prominent role. The ASFADA, the community umbrella organization which was formed in 2003 started being recognized as part of management and was able to influence decisions. The influencing role of KWS went down as the wider community started gaining trust in KFS and realizing that KFS had the mandate (importance) to manage gazetted forests and success requires their participation and inclusion. Figure 5 shows the influence and importance ranks of organizations participating in the management of ASF in 1999 and 2003.

In most instances, projects use networks and resources as tactics to coerce members to act in a certain way as was noted within ASFMT operations in ASF. In this paper, coercion has been used as defined by Turner (2005) as the attempt to control a target against their will and self-interest through the deployment of human and material resources to constrain and manipulate behavior. Resources are defined as anything an individual can make available to his or her partners to satisfy his or her partner's needs and to promote the attainment of his or her partner's goal, as described in resource theory (Simpson et al., 2015). In the ASF case, funds were directed to WGs to ensure change is achieved and would also push change from below (bottom-up). In ASFR, In \& Im analysis showed the above factors play a very important role. It also revealed that participation in decision-making, followed by participation in forest conservation and economic 


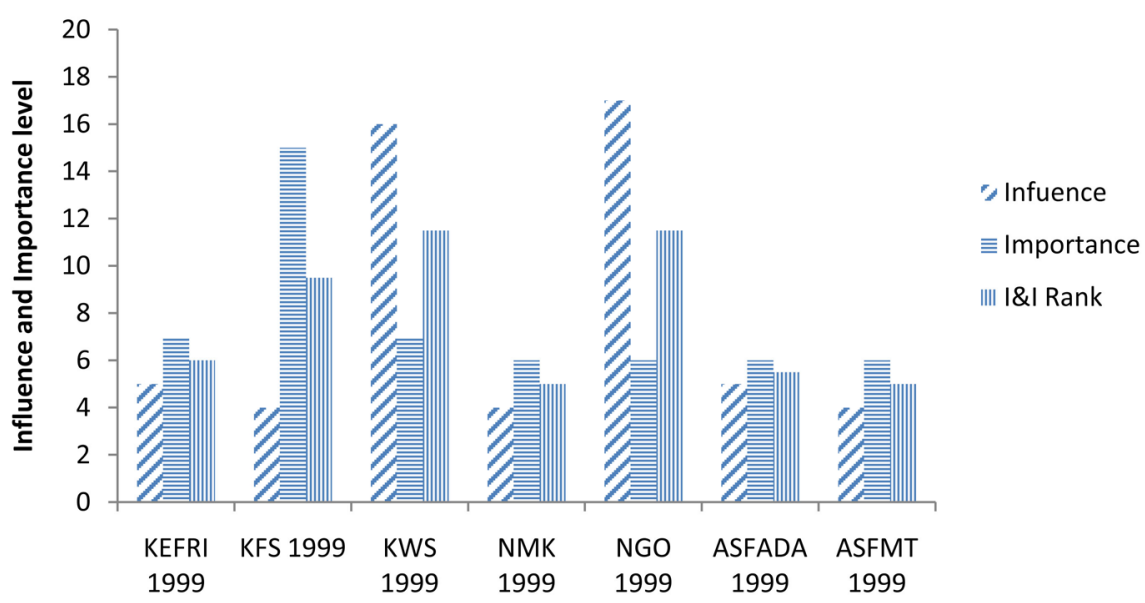

(a)

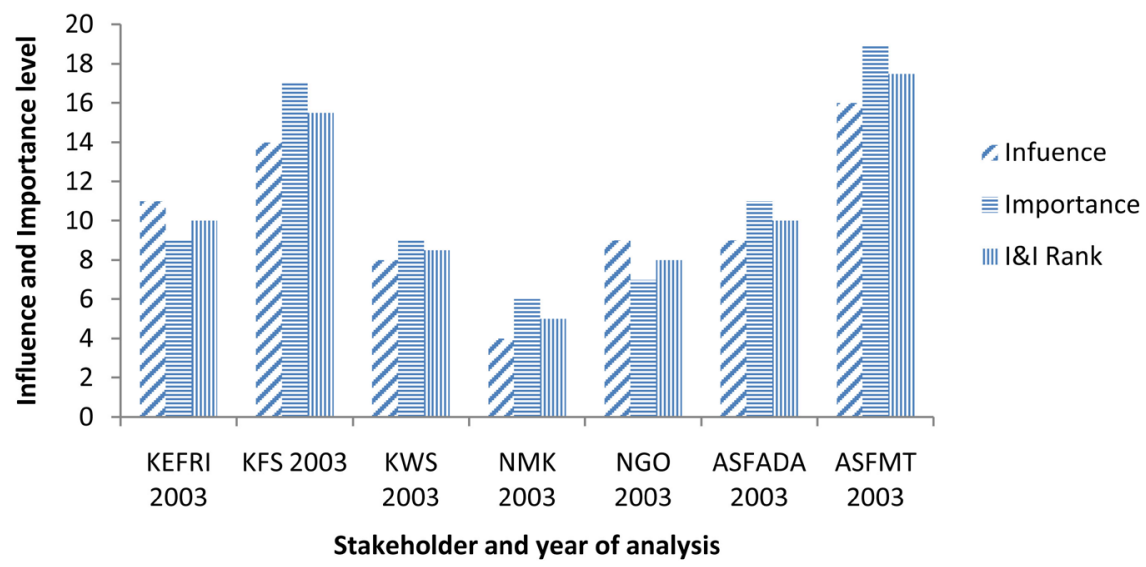

(b)

Figure 5. Trend Analysis of the level of influence and importance of organizations participating in the management of ASF in 1999 and 2003.

benefits were found to be the main factors influencing participation in forest management program as was noted by Coulibaly-Lingani et al. (2011). Further, the analysis indicated that participatory management program can be enhanced by changing the administrative structure of forest management groups in order to empower members (Coulibaly-Lingani et al., 2011).

\section{Lessons Learned from the Application of Influence and Importance Tool in ASFR}

A FMT paradigm brings up the premise of active participation which facilitates principles of participation, right-based approach to development and conservation and good governance as noted by Clarke \& Missingham (2009). These principles play a very important role in facilitating sustainable forest management. The In \& Im tool was used to re-activate the Teams (managed citizenship) and to assist in; Team building, re-stating team and project goals and objectives; build the management team; create a good understanding of the need to consult and assign roles to the organization with mandate (importance) to implement 
and more critically realize the need for individual stakeholders to manage their In \& Im dynamics. In ASFR as in other forests with similar FMTs, community groups are actively fundraising and managing projects. This scenario brings up new In \& Im dynamics which require stakeholders to adapt to and re-organize and engage within the changing platforms. Partners with mandate need to realize that other partners have the capacity and can assist in forest management.

The ASFMT which is an informal institution has shaped the performance of formal institutions as was noted by Helmke \& Levitsky (2004) where informal institutions tend to emerge where formal institutions are weak, lack credibility and lack authority. ASFMT was formed when KFS was weak and faced low levels of trust. The formation also assisted in realizing that there is a need to bring in adequate participation and allow those with skills to implement but with adequate consultation and ensure that decision making involves the right organization to get legal support (sanction). It also expanded the rights of stakeholders to participate in governance, and though not a legal entity, ASFMT's long existence, its national contributions and the subsequent replication of its structure by government has made it exercise influence nationally leading to a situation of it having de jure rights (Schlager \& Ostrom, 1992).

Improved use of influence which ignores important key stakeholders and critical procedures has a negative effect on project implementation and affects project sustainability negatively. On the contrary, maintaining good teamwork is very important for sustaining existing and future forest management teams as noted by Jacobs (2017). ASFMT is not a legal entity, though its long existence, good networks it has established and the national contributions it has had on forest management, community livelihoods and global interest it has attracted has influenced the government to replicate its structure, has made it exercise influence nationally leading to a situation of ASFMT having de jure rights (Schlager \& Ostrom, 1992).

Projects (read finance) play a very high influence role. This compares with the case in Indonesia where the government had to increase its allocation to supporting education as means to reduce and alter the dynamics of World Bank engagement (influence) (Edwards Jr. \& Storen, 2017).

The In \& Im tool creates a very open working system where team members work cautiously realizing that each member is aware of the expected individual In \& Im level in the Team; it improved communication and conflict management with stakeholders in ASF as noted by Tysiachniouk \& Laura (2015). The tool also lays bare to the stakeholders that unjustifiable use of In \& Im can result in a negative effect on the Team and poor implementation. It creates clientelism resulting in a scenario of deference and submissiveness on those without power towards those with influence (power). It further creates a more democratic and accountable partnership as noted by Clarke \& Missingham (2009). The Tool also demonstrates that any attempt to subdue the Team by any stakeholders may lead to team interruption. The tool can be used in various areas including; to streamline implementation Teams, form rural development teams, project implemen- 
tation teams, forest management Teams and improve communication and conflict management by stakeholders as was the case in ASF and noted by Tysiachniouk \& Laura (2015).

\section{Conclusion}

The ASFR FMT has exhibited resilience experiencing periods of low and high performance. This has been engendered through efforts of projects, donors, local and international experts and industry. During times of low funding, the ASF co-management business did not stall and its existence was sustained by the FMT institutional arrangement. During such periods, the Team was facing several management challenges including poor team-work that slowed implementation of project activities and conflicts. The communities would be less involved in the management and decision making. The Team was acting as a unifying factor and empowered people by giving them a common self-interest to pursue a shared goal of forest conservation and community livelihood improvement. Forest Management Teams (FMTs) are forming in Kenya as was noted for Caribbean Landscape Conservation Cooperative case and also in the framework of managing forest through pluralism. The ASF partnership as that in other forests in Kenya has been evolving and the emerging scenario has in most instances not been easy to predict. The changes have been more frequent in the last twenty years and have been more iterative in some cases eroding achievements gained. The FMTs have developed well-defined regulations, manual and norms. In Kenya, FMTs need to be recognized through the Forest legislation because it is widely used as a management framework in many forests in the country ranging from gazetted forests and parks, county forests, forests under lease and large private forest areas. This trend is coinciding with devolution in Kenya which is supporting emergent citizenship as happened in Acre in Brazil. In Kenya as was the case in Acre, participatory models of citizenship co-exist, forest-based models are emerging and nature is being commercialized as in the case of butterfly farming and eco-tourism but the partnerships are in a flux. Legal recognition of FMT's will ensure that the organizational structure is well-defined and the working formalities well-defined and embedded in law and thus the FMTs decisions more binding. Adequate awareness, understanding and consensus-building on Teams as an approach to forest management are required. In \& Im bring to the fore ethical consideration to forest management which is key to equity and fairness through consciousness aroused by the tool on the forest and other stakeholders.

\section{Conflicts of Interest}

The authors declare no conflicts of interest regarding the publication of this paper.

\section{References}

Anderson, J., Clément, J., \& Crowder, L. V. (2012). Accommodating Conflicting Interests 
in Forestry Concepts Emerging from Pluralism. Unasylva No. 194, Rome: FAO. https://dlc.dlib.indiana.edu/dlc/bitstream/handle/10535/8388/Accommodating\%20mul tiple\%20interests\%20in\%20forestry\%20concepts\%20emerging\%20form\%20pluralism\% 20-\%20Accommodatin.pdf?sequence $=1$

Ansong, M., \& Røskaft, E. (2011). Determinants of Attitudes of Primary Stakeholders towards Forest Conservation Management: A Case Study of Subri Forest Reserve, Ghana. International Journal of Biodiversity Science, Ecosystem Services \& Management, 7, 98-107. https://doi.org/10.1080/21513732.2011.613411

Arabuko Sokoke Forest Management Team (2002). Arabuko-Sokoke Forest Kenya: Strategic Forest Management Plan 2002-2027.

http://www.kenyaforestservice.org/documents/Arabuko.pdf

Arabuko Sokoke Forest Management Team (ASFMT) (2005). Arabuko Sokoke Forest Management Team; Conserving Arabuko Sokoke-Empowering Communities, Operational Guide, Malindi Kenya.

Balozi, B. K., Mbuvi, M. T. E., \& Wairungu, S. N. (2003). A Stitch in Time? Community Empowerment to Conserve the Arabuko Sokoke Forest. In XII World Forestry Congress (p. 5). Quebec: FAO Publication. http://www.fao.org/docrep/ARTICLE/WFC/XII/0612-A1.HTM

Banana, A. Y., Gombya-Ssembajjwe, W., \& Bahati, J. (1999). Decentralization of Forestry Resources in Ugansa: Rhetoric or Realities (p. 25). Uganda, Makerere University.

Benito, C. (2015). Environmental Citizenship in Action Environment and Citizenship. London and New York: Routledge.

Boateng, W. (2012). Evaluating the Efficacy of Focus Group Discussion (FGD) in Qualitative Social Research. International Journal of Business and Social Science, 3, 1-4.

Brenner, L. (2019). Multi-Stakeholder Platforms and Protected Area Management: Evidence from El Vizcaíno Biosphere Reserve. Mexico Conservation and Society, 17, 147-160. https://doi.org/10.4103/cs.cs_18_63

Clarke, M., \& Missingham, B. (2009). Active Citizenship and Social Accountability. Development in Practice, 19, 955-963. https://doi.org/10.1080/09614520903233571

Coulibaly-Lingani, P., Savadogo, P., Tigabu, M., \& Per-Christer Oden, P. (2011). Factors Influencing People's Participation in the Forest Management Program in Burkina Faso, West Africa. Forest Policy and Economics, 13, 292-302. https://doi.org/10.1016/j.forpol.2011.02.005

Edwards Jr., D. B., \& Storen, I. (2017). Influence over Time: Community-Driven Development and the Changing Nature of the World Bank's Impact in Indonesia. The International Education Journal: Comparative Perspectives, 16, 17-31.

https://openjournals.library.sydney.edu.au/index.php/IEJ

Folch-Lyon, E., \& Trost, J. F. (1981). Conducting Focus Group Sessions. Studies in Family Planning, 12, 443-449. https://doi.org/10.2307/1965656

Forest Department (2002). Arabuko Sokoke Strategic Forest Management Plan 2002-2027 Nairobi, Kenya.

Freitas, H., Oliveira, M., Jenkins, M., \& Popjoy, O. (1998). The Focus Group, a Qualitative Research Method. ISRC, Merrick School of Business, University of Baltimore (MD, EUA), WP ISRC No. 010298.

Government of Kenya (GoK) (2010). The Constitution of Kenya 2010. Nairobi: Government Printer.

Government of Kenya (GoK) (2016b). National Forest Programme (2016-2030). Nairobi: Ministry of Environment and Natural Resources, Government Printer. 
Government of Kenya (GoK) (2016a). The Forest Conservation and Management Act. Nairobi: Government Printer.

Helmke, G., \& Levitsky, S. (2004). Informal Institutions and Comparative Politics: A Research Agenda. Perspectives on Politics, 2, 725-740. https://doi.org/10.1017/S1537592704040472

Hobley, M. (1996). Participatory Forestry: The Process of Change in India and Nepal. Rural Development Forestry Study Guide 3. Rural Development Forestry Network. London: Overseas Development Institute. https://www.odi.org/sites/odi.org.uk/files/odi-assets/publications-opinion-files/8144.pdf

Jacobs, K. R. (2017). Teams at Their Core: Implementing an "All Lands Approach to Conservation" Requires Focusing on Relationships, Teamwork Process, and Communications. Forests, 8, 246. https://doi.org/10.3390/f8070246

Kenya Forest Service (KFS) (2009). Manual on Forming and Registering Community Forest Associations (CFAs) Kenya Forest Service and Kenya Forest Working Group. Nairobi.

Kenya Forest Service (KFS) (2015a). Participatory Forest Management Guidelines. Nairobi: KFS.

Kenya Forest Service (KFS) (2015b). Manual on Preparation of a Participatory Forest Management Plan (PFMP). Nairobi: KFS.

Kenya Forest Service (KFS), \& Kenya Wildlife Service (2012). Kakamega Forest Ecosystem Management Plan 2012-2022. Nairobi.

Kumar, K. (1989). Conducting Key Informant Interviews in Developing Countries. Agency for International Development. Program Design and Evaluation Methodology Report No. 13. Center for Development Information and Evaluation. https://doi.org/10.1002/ev.1516

Lutz, B., \& Newiadomsky, M. (2007). Fauna Threatened by Bushmeat Hunting? Investigation of the Status of Bushmeat Trapping in Arabuko-Sokoke Forest, Kenya. Wageningen: Van Hall Larenstein, Wageningen University.

Marshall, M. N. (1996). The Key Informant Techniques. Family Practice, 13, 92-97. https://doi.org/10.1093/fampra/13.1.92

Matiku, P., Mireri, C., \& Ogol. (2013). The Impact of Participatory Forest Management on Local Community Livelihoods in the Arabuko-Sokoke Forest, Kenya. Conservation \& Society, 2, 112-129. https://doi.org/10.4103/0972-4923.115724

Mbuvi, M. T. E., \& Musyoki, J. K. (2013). The Impacts of Participatory Forest Management on Community Livelihoods: A Case of Dida Community Adjacent to Arabuko-Sokoke Forest in Kilifi Count Kenya. World Journal of Agricultural Sciences, 1, 44-55.

Mbuvi, M. T. E., Ayiemba, O. W., \& Wambua, S. (2007). Costs and Benefits of the Arabuko-Sokoke Forest Reserve: Local, National and Global Level Perspectives; a Report for Prepared for CARE International.

Mbuvi, M. T. E., \& Ayiemba, W. O. (2005). Sustained Natural Resources Management and Community Livelihoods Improvement through Partnerships: The Case of Arabuko-Sokoke Forest Landscape in Kenya Presented during the 1st International Congress on Successful Cases in Sustainable Development in the Tropics (p. 30). Mexico, University of Veracruzana.

Ming'ate, F. M., Rennie, M. H. G., \& Memon, A. (2014). NGOs Come and Go But Business Continues: Lessons from Co-Management Institutional Arrangements for the Governance of the Arabuko-Sokoke Forest Reserve in Kenya. International Journal of Sustainable Development \& World Ecology, 21, 526-531. 
https://doi.org/10.1080/13504509.2014.968237

Ministry of Environment and Natural Resources (MENR) (1994). Kenya Forestry Master Plan Development Programmes (p. 318). Nairobi, Kenya.

Ministry of Environment, Water and Natural Resources (2015). Draft National Forest Policy, 2015. Nairobi: Government Printer.

Mugenda, O. M., \& Mugenda, A. G. (1999). Research Methods: Qualitative and Quantitative Approaches. Nairobi: African Centre for Technology Studies.

Myers, N., Mittermeier, A., Mittermeier, C. G., da Fonesca, G. A. B., \& Kent, J. (2000). Biodiversity Hotspots for Conservation Priorities. Nature, 403, 853-858. https://doi.org/10.1038/35002501

Ndalilo, L., Mbuvi, M. T. E., \& Luvanda, A. (2017). Utilization and Governance of Arabuko Sokoke Forest. In Biodiversity Status of Arabuko Sokoke Forest (pp. 47-59). Nairobi: Kenya Forestry Research Institute.

Ongugo, P. O., Mogoi, J. N., Obonyo, E., \& Oeba, V. O. (2008). Examining the Roles of Community Forest Association in the Decentralization Process of Kenyan Forests. In the IASC Conference (p. 27). http://citeseerx.ist.psu.edu/viewdoc/download?doi=10.1.1.510.2555\&rep=rep1

Paletto, A., Balest, J., De Meo, I., Giacovelli, G., \& Grilli, G. (2016). Power of Forest Stakeholders in the Participatory Decision Making Process: A Case Study in Northern Italy. Acta Silvatica et Lignaria Hungarica, 12, 9-22.

https://doi.org/10.1515/aslh-2016-0002

Phiri, M., Chirwa, P. W., Watts, S., \& Syampungani, S. (2012). Local Community Perception of Joint Forest Management and Its Implications for Forest Condition: The Case of Dambwa Forest Reserve in Southern Zambia. Southern Forests, 74, 51-59. https://doi.org/10.2989/20702620.2012.686203

Schlager, E., \& Ostrom, E. (1992). Property Rights, Regimes and Natural Resources: A Conceptual Analysis. Land Economics, 68, 249-262. https://doi.org/10.2307/3146375

Schmink, M. (2011). Forest Citizens: Changing Life Conditions and Social Identities in the Land of the Rubber Tappers. Latin American Research Review, 46, 141-158. https://doi.org/10.1353/lar.2011.0035

Schmink, M., Duchelle, A., Hoelle, J., Leite, F., D’oliveira, M. V. N., Vadjunec, J., Valentim, J. F., \& Wallace, R. (2014). Forest Citizenship in Acre, Brazil. In Forests under Pressure: Local Responses to Global Issues (pp. 31-47). IUFRO World Series No. 32.

Simpson, J. A., Farrell, A. K., Oriña, M. M., \& Rothman, A. J. (2015). Power and Social Influence in Relationships. In M. Mikulincer, \& P. R. Shaver (Eds.), APA Handbook of Personality and Social Psychology: Vol. 3. Interpersonal Relations (p. 28). Washington DC: American Psychological Association. https://doi.org/10.1037/14344-015

Thakur, R. B. (2011). Status of Governance in Community Forest Users Group (CFUGs) of Nepal: A Case Study from CFUGs of Surkhet District. M.Sc. Natural Resource Management, New Delhi: TERI University. https://www.academia.edu/5935590/Status_of_Governance_in_Community_Forest_Us ers_Group_CFUGs_of_Nepal_A_Case_Study_from_CFUGs_of_Surkhet_District

Turner, J. C. (2005). Explaining the Nature of Power: A Three-Process Theory. European Journal of Social Psychology, 35, 1-22. https://doi.org/10.1002/ejsp.244

Tysiachniouk, M., \& Laura, H. A. (2015). Managed Citizenship: Global Forest Governance and Democracy in Russian Communities. International Journal of Sustainable Development \& World Ecology, 22, 476-489.

https://doi.org/10.1080/13504509.2015.1065520 
Wass, P. (1995). Kenya's Indigenous Forests: Status, Management and Conservation. Gland and Cambridge: IUCN.

Wattoo, A. W., Ali, T., Khan, M. A. J., \& Shahbaz, B. (2010). Stakeholders' Role and Interactions in the Context of Forestry Extension Interventions in Northwest Pakistan. $\mathrm{Pa}$ kistan Journal of Agricultural Sciences, 47, 173-177. 


\section{Abbreviation Notation}

\begin{tabular}{|c|c|}
\hline ASFGA & Arabuko Sokoke Forest Guides Association \\
\hline ASFMT & Arabuko Sokoke Forest Management Team \\
\hline ASFR & Arabuko-Sokoke Forest Reserve \\
\hline CBOs & Community Based Organizations \\
\hline CFAs & Community Forest Associations \\
\hline CLCC & Caribbean Landscape Conservation Cooperative \\
\hline CSOs & Civil Society Organization \\
\hline DIFAAFA & Dida Forest Adjacent Area Forest Association \\
\hline FGD & Focus Group Discussion \\
\hline FMA & Forest Management Agreement \\
\hline FMTs & Forest Management Teams \\
\hline ICIPE & International center for Insect Physiology and Ecology \\
\hline Im & Importance \\
\hline In & Influence \\
\hline KEFRI & Kenya Forestry Research Institute \\
\hline KFS & Kenya Forest Service \\
\hline $\mathrm{KI}$ & Key Informant \\
\hline KIFCON & Kenya Indigenous Forest Conservation \\
\hline KWS & Kenya Wildlife Service \\
\hline MENR & Ministry of Environment and Natural Resources \\
\hline MoAs & Memorandum of Agreements \\
\hline MoUs & Memorandums of Understandings \\
\hline NMK & National Museums of Kenya \\
\hline NTFPs & Non Timber Forest Products \\
\hline PFM & Participatory Forest Management \\
\hline FD & Forest Department \\
\hline PFMPs & Participatory Forest Management Plans \\
\hline SMC & Senior Management Committee \\
\hline VDFCC & Village Development and Forest Conservation Committee \\
\hline WG & Working Group \\
\hline MEWNR & Ministry of Environment, Water and Natural Resources \\
\hline
\end{tabular}

